811.161.1'367.7:811.163.41'367.7

https://doi.org/10.18485/sj.2019.24.1.45

БЛАГОЈЕ В. ВУЈИСИЪ

доктор филолошких наука

Бијело Поље (Црна Гора)
Оригинални научни рад Примљен: 11. 09. 2018. Прихваћен: 15. 01. 2019.

\title{
КАТЕГОРИЈА ЛИЦА У ЈЕДНОЧЛАНИМ РЕЧЕНИЦАМА У РУСКОМ И СРПСКОМ ЈЕЗИКУ**
}

Овај тип реченица за истраживање категорије лица у раду је одабран због тога што је само дјелимично проучен и до сада нема јединственог и коначног мишљења о њему без обзира на актуелност проучавања његове семантичке структуре у посљедњих неколико деценија. Категорија лица детаљно је обрађена и описана у свим словенским језицима, али смо нашли ипак мало радова који се баве њеним описивањем у више словенских језика или у свим словенским језицима. Због тога смо сматрали да резултати наших упоређења сличности и посебно разлика могу бити корисни наредним истраживачима ове теме као и у наставне сврхе.

Основне задатке у изради овог рада формулисали смо на сљедећи начин: проучавање и опис категорије лица у једночланим реченицама на материјалу руског и српског језика; анализа еволуције погледа̂ на једночлане глаголске реченице у руском и српском језику; начини изражавања одређеноличности, неодређеноличности, уопштеноличности и безличности, као и начини изражавања конкретног лица (првог, другог и трећег); међусобно упоређивање и истицање карактеристика једночланих глаголских реченица, посебно по основу разлика у другом језику.

Кључне ријечи: категорија лица, једночлане реченице, одређеноличне реченице, неодређеноличне реченице, уопштеноличне реченице, безличне реченице, изражавање првог, другог и трећег лица.

\footnotetext{
*vujisicbp@t-com.me

${ }^{* *}$ Рад писан за зборник посвећен професору Радмилу Маројевићу (Српски језик XXIII).
} 
0.1. Категорија лица спада у категорије које формирају предикативну осу реченице и имају посебан значај за истраживање. За лингвисте она је универзална категорија „присутна у свим језицима и својствена истовремено и језику и мишљењу" [Шалютин 1980: 7] и једна је од основних језичких категорија. Разматрајући ову категорију ваља разликовати граматички аспект те категорије са морфолошким обиљежјима првога, другога и трећега лица једнине и множине, од њеног семантичкога аспекта, са значењски утврдивим ознакама личности и безличности. У разликовању граматичкога од семантичког аспекта категорије лица ваља разликовати и двије врсте садржаја које се означавају морфолошки утврдивим ознакама те категорије. Припадајући универзалним категоријама које се у разним облицима испољавају у језицима разних система, категорија лица, као и друге семантичке категорије, изражава не само индивидуалне особине, могућности човјека, учешће/неучешће у комуникацији, већ и онај социјални систем у који је он укључен, односно социјалне функције које он испуњава, а такође и националну етнокултурну специфичност општења сваког језичког колектива.

Крајем прошлог вијека у фази наглог напретка семантичког правца у синтакси највише недоумица стварало је питање једночланих реченица као самосталне синтаксичке категорије. Међутим, почев од 70-тих година прошлог вијека поједини руски синтаксичари покушали су да се одрекну појма „једночлана реченица” и да све просте реченице у руском језику подведу под категорију двочланости. Савремена лингвистичка наука даје предност комплексном, вишеаспектном прилазу за истраживање језичких јединица. Са ових позиција проучавају се управо једночлане реченице, и то са аспекта структуре, семантике, системских односа и језичког функционисања. Већина истраживача, посебно оних из ранијег периода истраживања ове категорије, имала је формалан приступ овој теми, са којим се ми, у принципу, не слажемо јер је суштина ових реченица прије свега семантичке природе.

Проучавајући и описујући категорију лица у једночланим реченицама на материјалу руског и српског језика, анализирали смо еволуцију погледа на категорију лица у ова два језика и специфичности структуре категорије лица у овим језицима. Основне дјелове рада представљају начини изражавања одређеноличности, неодређеноличности, уопштеноличности и безличности, као и начини изражавања конкретног лица (првог, другог и трећег). Обратили смо пажњу на њихово међусобно упоређивање и истицање њихових карактеристика, посебно по основу разлика у другом језику.

0.2. Истражујући историјат истраживања категорије лица и персоналности у руском и српском језику, напомињемо да је истраживање категорије лица почело у XIX вијеку у вези са проучавањем глаголских категорија; и сама категорија се третирала првенствено као граматичка категорија својствена глаголу. Већ у тим првим истраживањима аутори граматика и студија 
трудили су се да открију суштину граматичке личности и безличности, да одреде парадигму промјене, употребу у језику и сл. У својој књизи „Синтаксис русского языка” А. А. Шахматов је дао дефиницију личних глаголских облика која до данас није изгубила своју актуелност: „Лични глаголски облици је назив обиљежја у споју са пропратним представама о лицу које су повезане са представом о броју" [Шахматов 2001: 462]. Он први пут прилично детаљно разматра она значења са којима се могу употребљавати лични глаголски облици у једночланим и двочланим реченицама и описује значење безличног облика глагола.

У фундаменталном раду В. В. Виноградова „Русский язык” ова категорија глагола добила је најпотпунију анализу. Аутор је одредио категорију лица као „фундамент предикативности”, указао на синтетичке и аналитичке начине изражавања лица, на граматичке разлике облика првог и другог лица од облика трећег лица и размотрио значење и употребу личних глаголских облика и карактеристику безличних глагола.

Интересовање за категорију лица нагло је порасло почев од друге половине XX вијека, када се посебно истакао став Л. В. Шчербе да је категорија лица најкарактеристичнија глаголска категорија. Дефиниције категорије лица као граматичке категорије глагола налазе се у академским граматикама и лингвистичким рјечницима. У радовима за период 1950-1960. године категорија лица углавном се дефинише са тачке гледишта односа радње/стања и његовог субјекта. Савремена дефиниција семантике лица заснована је на дефиницији категорије лица коју је дао Р. О. Јакобсон: „Лице карактерише учеснике саопштаване реалне чињенице по односу према учесницима реалне чињенице саопштења" [Якобсон 1972: 100].

У лингвистичким енциклопедијским рјечницима категорија лица дефинисана је такође као комуникативна категорија. По угледу на Виноградова, сви наредни истраживачи приписивали су категорији лица посебну улогу у диференцијацији предикативности реченице - структури одговарајућег исказа. А у новијим истраживањима истиче се да се персонални садржај исказа гради на бази семантике предикативног лица. А. М. Пешковски је у личним замјеницама видио чисто граматичко значење, а В. В. Виноградов је видио сродност глаголске категорије лица са личним замјеницама и обратио пажњу на присуство у руском језику аналитичких и синтетичких облика изражавања лица. Оно што је он изрекао о синтаксичкој категорији лица послужило је као основ за проширено схватање лица. Тако је Г. А. Золотова прихватила ово мишљење, па је синтаксичко лице одредила као „аналогију субјекта - носиоца радње, стања, обиљежја о којем се саопштава у реченици једном од три лица учесника - неучесника комуникације" [1973: 158].

Савремени истраживачи семантику персоналности истражују на нивоу интегралног текста. За А. М. Пешковског лице је нужна категорија језичке 
мисли која јој припада по својој суштини, па без говорног лица не може бити ни говорне ситуације, говорно лице обавезно подразумијева слушаоца, а оба ова лица обавезно подразумијевају спољашњи свијет који их обухвата и који за њих представља треће лице [1956: 306]. У Граматици руског језика се истиче да облици првог, другог и трећег лица формално изражавају однос радње са њеним реалним вршиоцем који може бити и лице и предмет [Грамматика 1980: 636].

Пошто је обавезна карактеристика сваке реченице њена организација у односу на категорију лица, П. Пипер истиче да категорија лица, будући да је за српски као словенски језик типолошки карактеристична морфолошка категорија, истовремено је и реченична категорија јер у њеној реализацији учествују и предикатски израз, и аргументски израз [Пипер и др. 2005: 495].

На овај начин преглед најраспрострањенијих гледишта на категорију лица, а такође анализа фактичког материјала који припада писаним споменицима савременог руског и српског језика, омогућава да се она квалификује као функционално-семантичка категорија која врши важну улогу у формирању предикативности и комуникативног потенцијала реченице. А осим категоријалних значења лични облици индикатива посједују низ случајева употребе у одређеном контексту у свим личним облицима једнине и множине. Код руских и српских лингвиста углавном наилазимо на дефиниције да је прво лице оно које говори, друго је лице оно коме се говори, а треће је лице или предмет о коме се говори. Поједини аутори, као напримјер И. Стевовић, истичу да прво и друго лице не означавају само учеснике говорног чина већ су и предмет говора, док је треће лице искључиво лице или предмет о којем се говори. Према А. Белићу, пошто треће лице непосредно упућује на познато лице или предмет, оно је повезано са демонстративним и анафорским замјеницама, а пошто упућује на одсутно лице у комуникативној активности, оно се супротставља првом и другом као учесницима у говору, чиме се ствара опозиција која спаја треће лице са првим и другим у систему.

Истражујући категорију лица у савременом руском и српском језику, износимо да су проблеми који су везани за изучавање функционисања категорије лица добили важно мјесто у научној литератури и третирају се као универзална категорија. Категорију лица потребно је прво разматрати са интралингвистичког аспекта, па у том смислу лице је категорија конгруенције глагола са номинативом именице на коју се тај глагол односи. Надаље, категорију лица треба разматрати са екстралингвистичког аспекта, а то значи да њене дефиниције одражавају функционални прилаз опису категорије лица и карактеришу је као категорију која се манифестује прије свега у говорној ситуацији.

Када је у питању функционисање категорије лица у систему глаголских облика, истраживачи закључују да сви глаголи не реализују потпуну 
парадигму лица. У функционисању личних глаголских облика истраживачи примјећују да се лични облици могу употребљавати у другим, а не само у баш личном значењу. На основу наших досадашњих сазнања, питање категорије синтаксичког лица у глаголским једночланим реченицама захтијева стручно и свеобухватно истраживање.

1. Разматрајући специфичности категорије синтаксичког лица на материјалу једночланих глаголско-личних реченица, истичемо да се од граматичких обиљежја, упоредо са категоријама модалности и синтаксичког времена, издваја категорија синтаксичког лица чији се појам не третира увијек истозначно. Граматичка категорија лица има, прије свега, свој морфолошки израз у специјалним облицима замјеница и глагола. А морфолошку категорију лица увијек прати категорија броја: прво лице једнине, прво лице множине, друго лице једнине итд.; значење лица може бити изражено само синкретично са значењем броја. За синтаксичко лице карактеристичан је исти садржај као и за морфолошко лице јер их обједињује заједнички почетни моменат, а то је однос радње и вршиоца радње према субјекту радње/стања. Али за разлику од морфолошког лица, синтаксичко лице нема јасна формална обиљежја, јер оно не посједује ни облигаторност категорије броја нити супротстављеност облика. Даље, синтаксичко лице, пошто не посједује строгу супротстављеност облика, не карактерише се ни везаношћу тих облика за одређено значење.

Са тачке гледишта освјетљавања синтаксичког лица све једночлане глаголске личне реченице имају особину истозначности, тј. у њима је изражено значење лица-вршиоца радње, па у одређеноличним реченицама то су говорно лице и слушалац, у неодређеноличним - лице или лица о којима се говори, тј. трећа лица итд. Могућност трансформације једночланих реченица са облицима првог и другог лица у двочлане реченице одређеног типа (и обрнуто: двочланих у једночлане реченице) није случајна. У једночланим структурама са облицима трећег лица таквог семантичког суодноса нема. Одређеноличним и неодређеноличним реченицама својствено је семантичко-граматичко јединство, а уопштено значење није условљено граматичком структуром реченице.

Синтаксичку структуру одликује у свом садржају однос према стварности не само у одређеној модалности - као реалност-иреалност и синтаксичком времену, него и у вези са тим или другим синтаксичким лицем носиоцем радње, стања, обиљежја, у нашем случају са лицем вршиоцем радње, узрочником радње.

Истражујући мјесто једночланих реченица у класификацији просте реченице, увиђамо да у синтакси просте реченице и даље постоје спорна питања која се тичу класификације просте реченице, посебно класификације једночланих реченица. Питање ових реченица, њихов граматички статус, граматичка природа главног члана, рјешавана су у лингвистици на разне начине. 
2. Истражујући категорију одређености, односно одређеноличне конструкције, истичемо да у савременим синтаксичким истраживањима питање о њиховом издвајању у својству самосталне синтаксичке категорије још није до краја ријешено, али ипак већина синтаксичара у групу једночланих реченица издваја и одређеноличне.

Једна група лингвиста ове конструкције сврстава у двочлане непотпуне реченице на основу тога што је у њима субјекат (мада лична замјеница изостаје) изражен у личном глаголском облику. Друга група поништава граматичку специфичност једночланих реченица на тај начин што проширују категорију одређеноличних реченица на све двочлане конструкције, јер је у њима субјекат суда (вршилац радње или предмет) изражен посебном ријечју, односно откривен је са крајњом јасноћом.

Граматичка природа ове конструкције заснива се на могућности глаголског облика да изражава и радњу, и да указује на вршиоца те радње, да изазива „представу и о предикату и о субјекту” [Шахматов 1941: 50].

У низу језика, па тако и у руском и у српском, лична замјеница се не мора употријебити кад има функцију субјекта, јер ти језици имају изразито развијене личне глаголске облике из којих је видљиво је ли субјекат у 1,2 . или у 3 . лицу. У руском језику присуство субјектне личне замјенице је уобичајено, а њено изостављање стилски маркирано. У српском језику лична замјеница у функцији субјекта се испушта ако није контрастирана или посебно наглашена; уп. Путујем на море наспрам Ја путујем на море (а не ти) [Kordić 2002: 12].

Одређеноличне реченице имају широку употребу у разговорном језику, посебно у дијалогу. Оне придају језику динамичност и употребљавају се онда када се радња одређеног лица изражава без неког супротстављања, упоређивања, доказивања нечега и сл. За разговорни језик ове реченице су нормативне и стилски неутралне. Аутори приповједачког стваралаштва користе ове реченице за исказивање сопствених радњи, мисли, осјећања. Употребљавају се у умјетничко-белетристичком стилу, у умјетничкој и друштвено-политичкој публицистици (новине, часописи). Употреба ових реченица карактеристична је и за научни стил са предикатом, углавном, у првом лицу множине (рјеђе једнине). На овај начин употреба одређеноличних реченица у стиловима и типовима говора савременог руског и српског језика одликује се разноврсношћу која је условљена њиховом семантичко-граматичком суштином.

Одређеноличне реченице имају ту предност да могу избјећи лексичко понављање у позицији субјекта, чиме се постиже стилски ефекат. Савремена лингвистика не спори издвајање одређеноличних реченица у посебан структурно-семантички тип, без обзира на то што су оне свој статус добиле касније од осталих једночланих реченица. Непостојање субјекта у одређеноличним реченицама не утиче на формирање структурне схеме ових реченица јер се 
предикативни односи (основ било које просте реченице) успостављају исто тако као у двочланим реченицама између два појма: појма који се суодноси са предметом говора, субјектом, и предикативним обиљежјем који се приписује предмету говора, предикату, који је означен предикатским обликом ријечи.

О питању статуса трећег лица постоје неслагања, без обзира на то што, по нашем мишљењу, оно са првим и другим лицем равноправно учествује у формирању категорије лица и броја. У овом смислу А. М. Пешковски је писао да „У трећем лицу субјекат може да буде не само лична ријеч он, него и хиљаде других ријечи са разноврсним значењима" [Пешковский 1956: 186].

Можемо констатовати да су једночлане одређеноличне реченице потпуна категорија, а одсуство субјекта у њима је синтаксичка норма оба језика. Уосталом, субјекат и није потребан у њима јер је вршилац радње одређен личним глаголским завршецима као говорно лице или слушалац.

На материјалу романа „Окамењена нимфа” М. Ћупића на српском језику нашли смо да је за 38\% број ових реченица мањи у руском преводу. Конкретно, најмање промјене у питању употребе личних замјеница претрпјеле су одређеноличне реченице са глаголским обликом у другом лицу једнине, а затим слиједе одређеноличне реченице са глаголским обликом у другом лицу множине. Одређеноличне реченице са глаголским обликом у првом лицу једнине и одређеноличне реченице са глаголским обликом у првом лицу множине имају једнаку средњу вриједност промјена ове врсте, а даље слиједе одређеноличне реченице са глаголским обликом у трећем лицу множине и са највише промјена у погледу употребе личних замјеница - одређеноличне реченице са глаголским обликом у трећем лицу једнине.

Ови показатељи се објашњавају особином ова два језика када је у питању употреба личних замјеница која је у оба језика прилично заступљена. Наиме, употреба личне замјенице у односу на лични глаголски облик не садржи додатну информацију о природи вршиоца радње. Оне су више лексичка него морфолошка средства за изражавање семантике лица јер не посједују личне наставке за изражавање личног значења као лични облици глагола, па се лично значење изражава посебним обликом, као на примјер лично значење замјенице „ми” најчешће је изражено глаголским наставком, па је оно дио његовог значења. Посебно је ова употреба обавезна у руском језику када је у питању прошло вријеме, које се у том језику изражава аналитичким путем, односно спојем личних замјеница са обликом који изражава прошло вријеме. Веза између личних замјеница и глаголских наставака обавезнија је у руском него у српском језику, што је посљедица губљења употребе копулативног глагола. Отуда се у конструкцијама са овим глаголом најбоље види неопходност присуства личних замјеница које су носиоци значења категорије лица. 
На основу анализираног материјала можемо закључити да се одређеноличне реченице које означавају радњу говорног лица употребљавају и у руском и у српском језику (као и у осталим словенским језицима). Рјеђе се употребљавају у руском него у српском језику зато што руски нема у прошлом времену у употреби глагол са диференцираним наставцима ни у једном лицу једнине или множине

3. Радећи истраживање о неодређеноличним реченицама, налазимо да се главни члан неодређеноличних реченица изражава промјенљивим обликом глагола множине, у садашњем и будућем времену обликом трећег лица множине, прошлим временом и кондиционалом множине. Избор граматичких средстава за изражавање неодређеног синтаксичког лица није случајан. Наиме, глагол у трећем лицу множине у једночланој реченици не конкретизује субјекат радње или носиоца предикативног обиљежја. Синтаксичка семантика неодређеноличних реченица је радња, стање неодређеног субјекта. Неодређеност субјекта има сљедеће значење: субјекат у стварности постоји, али говорно лице исказује радњу не правећи њену корелацију са субјектом, долази до „отуђења” радње од субјекта. Уз то у реалној стварности субјекат може бити у потпуности и одређен. Неодређенолично значење реализује се обликом множине која се употребљава у посебном граматичком значењу: не у директном (радња неколико субјеката), већ у преносном (радња неодређеног субјекта). Парадигма неодређеноличних реченица је пун облик множине у било ком начину и времену.

У науци о језику ове реченице нису третиране једнообразно. Први је на неодређеноличне реченице указао Н. Греч, а први их је описао и увео термин „неодређенолични глаголи” Д. Н. Овсјанико-Куликовски. Прву класификацију и теоретски основ једночланих реченица урадио је А. А. Шахматов.

У Граматици руског језика из 1948. године у редакцији И. В. Шчербе једночлане глаголске реченице дијеле се на безличне и неодређеноличне. У издањима Академијине Граматике руског језика (у редакцији В. В. Виноградова и Ј. С. Истрине) из 1954. и 1960. године за неодређеноличне реченице се каже да означавају радњу коју врше неодређена лица. У Граматици савременог руског књижевног језика у издању из 1970. године (у редакцији Н. Ј. Шведове, која је и аутор одјељка о овим реченицама) неодређеноличне реченице се разматрају у одјељку двочланих реченица као непотпуна реализација структурне шеме $\mathrm{N}_{1} \mathrm{Vf}$ заједно са реченицама типа Читаешь. Читай! (са изостављеним субјектом) и означавају радњу лица које се замишља као неодређено. У издању Академијине Руске граматике (1980) у одјељку „Структурные схемы (типы) простых невопросительных предложений” под насловом Предложения типа Стучат; Зовут говори се о неодређеноличним реченицама (схема $\left.\mathrm{Vf}_{3} \mathrm{p}_{1}\right)$, чија је парадигма седмочлана. Чешки аутори M. Balcar, M. Dlouhý и M. Kubík y књизи „Синтаксис русского языка” у одјељку „А. Глагольные односоставные 
предложения" дају пет структурних модела једночланих реченица, од којих су трећи модел реченице типа Школу ремонтируют (Здесь говорят по-русски) (схема Vf $3 \mathrm{pl}+\mathrm{N}$ non $\mathrm{n} / \mathrm{Adv}$ ).

Михаило Стевановић одваја од реченица без субјекта „реченице са обликом предиката у 3. л. мн. глагола говорења и писменог саопштавања" као што су: Говоре по селу. [Стевановић 1969: 34]. Миодраг С. Лалевић ове реченице заједно са уопштеноличним сврстава у једну групу - групу „неопредељено-личних или неодређено-личних реченица” из разлога што у њима „лице овде није опредељено” [Лалевић 1962: 161]. Игрутин Стевовић у својој „Функционалној граматици српскохрватског језика" дотиче се питања неодређеноличних реченица, на што указујемо у одјељку о уопштеноличним реченицама [Стевовић 1960: 49-58]. Бавећи се на научно утемељеној теоријској основи проучавањем неодређеноличних реченица у руском језику и проблемима њиховог превођења на српски језик Радмило Маројевић је нашао недостатке у дефиницијама ових реченица у граматикама руског језика, па чак и у Граматици АН СССР, и дошао до најпотпуније дефиниције ових реченица која гласи: „Неодређеноличне реченице су реченице у којима се не исказује вршилац радње, јер је непознат, неодређен, уопштен, или је одређен и познат, али се ставља у други план да би се истакла радња као таква" [Маројевић 2000: 220].

Без обзира на релативно сиромаштво формално-конструктивних особина неодређеноличне реченице су веома разноврсне по својим структурним и семантичким типовима. С обзиром на разлике у начину изражавања лица можемо разликовати три типа ових реченица: праве неодређеноличне реченице, одстрањено-неодређеноличне реченице и односне неодређеноличне реченице. У роману „На Дрини ћуприја” ова разноврсност није дошла до изражаја у свим овим типовима реченица, што ћемо и навести бројчано и процентуално. Наиме, у њему су скоро 99\% заступљене праве неодређеноличне реченице, односне неодређеноличне са $1 \%$, дочим одстрањено-неодређеноличне реченице уопште нису заступљене.

У савременом руском и књижевном и говорном језику неодређеноличне реченице су у широј употреби него што су то у српском језику, како у писаној тако и у усменој варијанти. Без обзира на релативно сиромаштво формално-конструктивних особина неодређеноличне реченице су веома разноврсне по својим структурним и семантичким типовима.

4. Урадивши анализу уопштеноличних реченица констатовали смо да је питање статуса тзв. уопштеноличних реченица једно од најспорнијих у словенској синтакси. Ово због тога што је појам уопштеноличности у ранијој синтаксичкој литератури повезиван са типом једночланих реченица чији је главни члан изражен обликом глагола у другом лицу једнине, а у новијим радовима преовладава семантички приступ реченици, па се сретају мишљења 
да се не ради о посебном типу (једночланих) реченица и да оне нису везане за неки структурни тип реченице као што су то неодређеноличне и безличне реченице. Проблем чини мијешање два принципа класификације просте реченице - формалног и семантичког, због чега је понекад немогуће одредити којем типу припада одређена реченица.

У уопштеноличне реченице убрајају се структуре са главним чланом у глаголском облику другог лица једнине који саопштава синтаксичко значење уопштеног субјекта; облик другог лица не употребљава се у свом основном значењу - радња адресата, већ у преносном - радња уопштеног лица. Структурна схема уопштеноличних реченица може се представити ca Vf2s, а уопштеност значења ових реченица произлази из њихове припадности сентенцама, пословицама, афоризмима. Овакав приступ овим конструкцијама не може се назвати граматичким. Са структурне тачке гледишта поменуте реченице припадају другим типовима: неодређеноличним, одређеноличним, двочланим (непотпуним). У Руској граматици из 1980. године овај тип реченица не издваја се као посебна структурна схема, реченице са главним чланом у облику другог лица једнине без субјекта разматрају се као непотпуна реализација двочлане реченице (N1-Vf). Основ за то је управо могућност изражавања уопштеноличног значења и уз присуство субјекта $\mathrm{mbl}$.

Сасвим нов приступ овом питању имао је А. М. Пешковски. Према његовом мишљењу, реченице чији је главни члан изражен обликом другог лица „представљају омиљен облик личног уопштавања у руском језику и то чини његову важну синтаксичку карактеристику" [Пешковски 2001: 341]. В. В. Виноградов у свом раду „Русский язык” уочава уопштенолично значење личних глаголских облика. Он сматра да се у личним облицима, са своје стране, облик другог лица употребљава као уопштенолични. Вера Николић, говорећи о неодређеноличном значењу глагола у руском језику, ослања се на мишљења оних руских граматичара који говоре о неодређеноличном значењу глагола у случајевима када се глаголска радња приписује неодређеном кругу лица или свима.

У Граматици савременог руског књижевног језика из 1970. године уопштеноличне реченице се не издвајају као посебна синтаксичка категорија, већ се сматрају обичном формом синтаксичког индикатива двочланих реченица. У издању Академијине Руске граматике из 1980. године у одјељку „Структурные схемы (типы) простых невопросителных предложений” уопштеноличне реченице се не издвајају као посебан тип реченица

Г. А. Золотова је иступала против традиционалне класификације и издвајања једночланих реченица (не само уопштеноличних, већ и неодређеноличних и безличних). Н. Ј. Шведова тврди да је потпуно неправилно издвајање у својству посебне синтаксичке структуре тзв. уопштеноличних реченица. 
Слично мишљење има Н. С. Валгина, која сматра да у уопштеноличне реченице треба убројати и двочлане реченице у којима се субјекат, изражен личном замјеницом, употребљава у значењу уопштеног лица. А. А. Шахматов је објаснио „замјену” првог лица облицима другог лица у уопштеноличним реченицама: „говорно лице, испољавајући своју личност, говори у првом лицу; али одлазећи у себе, у своје успомене, репродукујући своја унутрашња преживљавања, природно прибјегава другом лицу, чинећи себе објектом свог говора" [Шахматов 2001: 73]. Одсуством спољашњег (споредног у односу на говорно лице) адресата могуће је објаснити и ту особину уопштеноличних реченица на коју је указао А. М. Пешковски: „у форму обраћања облаче се неријетко чисто личне чињенице које носе дубоко интимни карактер" [1956: 375]. Граматика руског језика из 1948. године у неодређеноличне сврстава и реченице типа „Что посеешь, то и пожнешь”, односно у групу реченица типа „Сегодня в киоске продают много новых книг”.

У синтакси српског језика у мањем обиму су разрађени типови ових реченица, него у синтакси руског језика. Радмило Маројевић на научно утемељеној основи с правом сматра да уопштеноличне реченице нису једночлане (осим оних у којима је у предикату глагол у трећем лицу множине), јер у свима њима субјекат је могућ и конгруентан са предикатом, као и код свих других личних реченица ${ }^{1}$. Сличан приступ сретамо у Синтакси савременог српског језика [Пипер 2005: 602-603].

Старија Академијина граматика сврстава у уопштеноличне и реченице са предикатом у облику трећег лица множине садашњег времена, које не могу имати субјекат-замјеницу са уопштеноличним значењем. Међутим, код Р. Маројевића оне су по форми неодређеноличне реченице које изражавају различита уопштенолична значења. Пошто се у руском језику уопштенолично значење најчешће везује за друго лице, Милка Ивић сматра да у руском језику „употреба другог лица једнине за означавање уопштеног агенса већ излази из оквира уско стилистичког", за разлику од српскохрватског језика, у коме се овај тип реченица везује за „специфични, експресивни ниво изражавања” [Маројевић 1977: 103]. Миодраг С. Лалевић ове реченице заједно са неодређеноличним сврстава у једну групу - групу „неопредељено-личних или неодређено-личних реченица” из разлога што у њима „лице овде није опредељено” [Лалевић 1962: 161]. Игрутин Стевовић у својој „Функционалној граматици српскохрватског језика” говори о „двочланим реченицама са уопштеним субјектом”.

Према томе, једна од најважнијих семантичких особина уопштеноличних реченица састоји се у томе да се оне употребљавају за изражавање оних појава које говорно лице схвата као својеврсно обавезне, неоспорне и аксиоматичне.

${ }^{1}$ О овоме је више пута писао Радмило Маројевић [Маројевић 1984: 27-33; Маројевић 2000: 234-247; Мароевич 2001: 135, 193. 
Управо због тога се у уопштеноличним конструкцијама чува значење „свеопштости" појава, њихове односности према било ком лицу ако оно доспије у аналогну ситуацију.

Фонд уопштеноличних реченица у анализираном материјалу је богат са аспекта формалних типова које смо издвојили, зависно од структуре уопштеноличних реченица и од начина изражавања предиката, али оне имају ограничену употребу јер се употребљавају у специјалном контексту.

Од укупно 78 једночланих уопштеноличних реченица у роману „Тврђава” Меше Селимовића на српском језику, уопштеноличних реченица са обликом глагола у другом лицу једнине индикатива има 59 (76\%) реченица, уопштеноличних реченица са обликом глагола у другом лицу једнине заповједног начина - 2 реченице (3\%) (односно уопштеноличних реченица са обликом глагола у другом лицу једнине има 61 (78\%) реченица), уопштеноличних реченица са обликом глагола у првом лицу множине - 12 (15\%) реченица, уопштеноличних реченица са глаголот у облику прошлог времена у оба језика, као и аориста и потенцијала у српском језику - 4 (5\%) реченице и уопштеноличне реченице са обликом глагола у трећем лицу множине - 1 (1\%) реченица. Нисмо нашли уопштеноличне реченице са обликом глагола у првом и трећем лицу једнине.

С обзиром на узајамни однос елемената граматичког облика главног члана, спрезно-глаголских једночланих уопштеноличних реченица у овом роману било је 47 (60\%) реченица, спонско-инфинитивних 20 (26\%), спонско-именских 8 (10\%) и спонско-глаголских 3 (4\%) реченице - укупно 78 реченица.

Ово нису сви типови једночланих уопштеноличних реченица који постоје у руском и српском језику. У анализираном материјалу нисмо пронашли, напримјер, уопштеноличне реченице са глаголским обликом у другом лицу множине индикатива садашњег или будућег времена. Те реченице помињу, уосталом, и аутори академских граматика и други аутори.

Из анализе ових реченица може се закључити да се оне у руском и српском језику подударају на семантичком плану, а да се разликују формалним показатељима уопштености, као и односом између њиховог семантичког и формалног плана. За овај тип не можемо примијенити појам граматичке категорије реченице, уколико посебни типови личних реченица немају своје јасно означене моделе који би били формални показатељи семантике сваког од ових типова.

5. На основу анализе безличних реченица стекли смо утисак да су оне најсложенији тип једночланих реченица, а да је безличност као појам семантичко-граматичка категорија. Категоријално значење безличности манифестује се на семантичком и граматичком нивоу система језика и има специјализована средства изражавања. У савременом српском језику ове реченице се у своме 
стандардном виду образују на основу два модела: као субјекатско-предикатске конструкције и као бесубјекатске конструкције. Ове бесубјекатске или безличне реченице реализују се увијек тако да се у њима не може отворити синтаксичка позиција за актант који заузима синтаксичку позицију субјеката у реченици [Стевановић 1991; Ivić 1963].

На основу анализираног материјала закључујемо да се ове реченице у ова два језика често јављају, и то како са непрелазним тако и са прелазним глаголима. Ово се објашљава тиме што се у неким функционалним стиловима све више тежи ка анонимизацији. Управо због своје разноврсности структурних различитости и одговарајућих синтаксичких значења и велике продуктивности њима треба посветити више пажње при опису савременог српског стандардног језика у свим његовим функционалним стиловима. Ова карактеристика се односи и на руску језик, па је довољно рећи да се у „Руској граматици” на безличне реченице односи 14 структурних схема.

Безличне реченице су најјача категорија у систему једночланих реченица. Због тога П. А. Лекант сматра да је безлична реченица један од најсложенијих и необично еластично организованих фрагмената граматичког система руског језика. За протеклих двјеста година ове реченице су детаљно проучаване од стране филолога са разних аспеката: логичко-граматичког, семантичког, дијахроног, а русисти су им посветили три докторске дисертације. Али без обзира на овај допринос питање безличних реченица остаје и даље отворено и дискутабилно. Академијина граматика из 1970. године однос безличности и личности третира на сљедећи начин: „облик трећег лица једнине може означавати безличност, тј. указивати на то да вршење радње произлази независно од њеног вршиоца (лица или предмета), нпр.: светает, смеркается, naxнет (сеном), хочется, верится, нездоровится..." [1970: 363].

За Милку Ивић безличност је дио категорије лица, па истиче да је образовање реченице условљено присуством личног наставка у глаголском облику, а није условљено присуством експлицитне именичке форме - субјекта. Повезаност безличности са категоријом лица видљива је код Михаила Стевановића када истиче да безличне реченице не могу бити природно везане ни за једно лице, оне немају свог посебног облика, него се употребљавају у облику једног од познатих лица - у ономе наравно што је најнеутралније, тј. у облику трећег лица једнине и неутралног граматичког рода, тј. у облику средњег рода. У Синтакси просте реченице стоји да се помоћу категорије персоналности „може реферисати о учесницима у говорној ситуацији (говорно лице и адресат), као и о неком трећем лицу, предмету или апстрактној појави, независно од тога да ли су то лице, тај предмет или та појава присутни у говорној ситуацији или нису” [Пипер и др. 2005: 592].

На основу ових и других примјера видимо да се мишљења у одређивању оквира и међусобних односа граматичке личности и граматичке безличности 
веома разликују. Начини изражавања су слични у руском и српском језику, али постоје битне разлике у вези са ставовима које структуре треба третирати као безличне, чак и у оквиру истог језика. С обзиром на разлике у погледу типова изражавања безличности, сретамо битне разлике у изражавању истог типа безличности, што се одразило и на терминологију: безличные предложения, бесподлежащные предложения, имперсональные предложения; безличне реченице, бесубјекатске реченице, апсолутно бесубјекатске, релативно бесубјекатске, имперсоналне реченице, неноминативне реченице.

Постоје два прилаза класификацији безличних реченица - структурни и семантички. Када је у питању семантичка класификација ових реченица, према семантичким типовима предиката, на материјалу романа „Мајстор и Маргарита" у преводу на српски језик нашли смо све типове ових реченица које помињу аутори који су се њима бавили. Од укупног броја безличних реченица у овом роману (1034 реченице) безличних реченица глаголских конструкција нашли смо 729 реченица, што чини 70 \% укупног броја ових реченица, што значи да на безличне инфинитивне и безличне реченице именског типа отпада 305 (29\%) реченица.

Истражујући структурне аспекте категорије лица у једночланим реченицама, дошли смо до сазнања да нам је спроведена анализа теоретске литературе на тему третирања категорије лица омогућила да закључимо да је савремено разматрање категорије лица засновано на опширном лингвистичком искуству разних научних погледа.

6. Када је у питању изражавање првог лица можемо закључити да се одређеноличне реченице које означавају радњу говорног лица употребљавају и у руском и у српском језику (као и у осталим словенским језицима). Рјеђе се употребљавају у руском него у српском језику зато што руски нема у прошлом времену у употреби глагол са диференцираним наставцима ни у једном лицу једнине или множине. У реченицама са глаголима који изражавају захвалност, молбу, извињења, поздраве и сл. (поздравляю (с праздником), благодарю, желаю (счастья), надеюсь, извиняюсь, кланяюсь...), категорија лица је представљена као прво лице, односно у употреби су одређеноличне конструкције.

Одређеноличне реченице које у саставу главног члана имају глагол „бити, имати”, као и глаголом „бити” са значењем „налазити се, присуствовати” у садашњем и прошлом времену не постоје у руском. За изражавање првог лица множине важе иста правила као и за прво лице једнине, односно прво лице једнине може бити изражено двочланом или једночланом конструкцијом, с тим што су једночлане конструкције за изражавање првог лица множине чешће, пошто су неке ситуације једночланости карактеристичне само за изражавање првог лица једнине (ситуације са конструкцијама са глаголима који означавају захвалност, молбу, извињење, поздраве и сл.). 
Употреба облика са пренесеним значењем првог лица присутна је у оба језика (а и у свим словенским језицима), што се објашњава тиме да је говорно лице учесник или стваралац сваког говорног чина. Облици првог лица множине у различитим ситуацијама користе се у функцији првог лица једнине у оба језика и то је један од најчешћих случајева употребе неких облика у пренесеном значењу.

У руском језику веома чест начин изражавања првог лица са различитим модалним нијансама јесте облик другог лица императива. То су обично значења дужности, жеље, необавезне или неочекиване радње. У српском језику се не користе ови облици у овом значењу, већ у нешто другојачијем - са значењем морања, обавезе: Трпи кад ниси умио (о себи). У оба језика присутна је употреба трећег лица једнине у функцији првог лица једнине са различитим стилским ефектима. Облици трећег лица множине и облици прошлог времена у руском језику могу да вежу радњу за једно лице у случајевима када се има у виду да је субјекат радње говорно лице: - Молчи, тебе говорят! У српском ова замјена није могућа, него се употребљавају личне реченице или реченица са рефлексивним пасивом: Ћути, када ти кажем (када ти се каже).

Облици трећег лица множине и облици прошлог времена у руском језику могу да се употребљавају умјесто облика једнине за изражавање уважавања, поштовања или покорног односа; такве односе често прати употреба облика множине личне замјенице (именице). Оваква употреба није карактеристична за српски језик, али неки преводиоци је употребљавају и тиме успјешно дочаравају систем односа и конверзацију времена у којем се радња дјела одиграва.

Прво лице у руском језику може бити изражено и безличним облицима глагола, а из контекста се види да се ради о првом лицу. За српски језик оваква употреба није карактеристична. За изражавање првог лица у руском језику користи се инфинитивна конструкција, а у оваквим ситуацијама у српском језику могућа је само лична конструкција.

У изражавању првог лица једнине нема битних разлика између руског и српског језика јер се прво лице изражава личним глаголским обликом и личном замјеницом која није обавезна, али из одређених разлога може се а некада и мора се употријебити. Пошто је у глаголском облику садржана ознака за лице, онда су у руском и српском језику чешће употребљавају једночлане, одређеноличне реченице. Заступљеност одређеноличних реченица у руском језику је мања због одсуства диференцијације глаголских наставака у прошлом времену, што је условљено губљењем облика помоћног глагола быть.

Једночлане одређеноличне реченице са глаголом имати у којима се говори о положају субјекта веома ријетко се употребљавају у руском језику јер су за њега карактеристичне синонимичне конструкције типа Уменя есть время. Руски језик такође нема у садашњем времену конструкцију чији је главни 
члан изражен ријечима са значењем дужности и инфинитивом одговарајућег глагола, као што је то случај са српским језиком у којем умјесто инфинитива може се употријебити везник $\partial а$ и лични облик глагола. Употреба личне замјенице у српском језику није обавезна у ситуацији када је то у руском нужно у случају употребе замјенице-субјекта када је предикат изражен обликом који морфолошки не указује на лице, па се употребљава помоћни глагол који указује на лице. А насупрот овоме, постоје случајеви обавезне употребе личних замјеница у одређеноличним реченицама у формалној структури реченице. Облик првог лица множине може се срести у проширеној употреби у једночланим реченицама у којима се радња приписује многима (свима), укључујући и говорно лице а не искључујући саговорника. Од овакве употребе треба рзликовати употребу првог лица множине када се означава заједничка радња говорног лица и лица коме је порука упућена. Облик другог лица у значењу првог може да представља радњу која се односи само на говорно лице, као и радњу која се доживљава као уопштена.

7. Уопште узев, за облике другог лица категоријална значења представљају повезаност радње са саговорником а у множини повезаност радње са групом лица, укључујући и саговорника. Поред дијалога, облици индикатива другог лица чести су и у другим ситуацијама, као што је употреба другог лица једнине у писмима или писменим саопштењима са конкретним адресатом. Облици индикатива другог лица присутни су у високом, свечаном стилу обраћања отаџбини, народу, симболима као живим бићима, затим у случајевима указивања на опасност, муку, тешкоћу, давања упутства како да се ове и сличне недаће избјегну.

Многозначност форми другог лица често се испољава у конструкцијама са обликом првог лица множине који се употребљавају за означавање радње или стања другог лица или лица без учешћа говорног лица. Надаље, друго лице једнине може бити у оба језика изражено првим лицем једнине (обраћање дјетету или кућном љубимцу напримјер). Треће лице у функцији другог лица може да служи као форма неком присутном при изражавању посебног уважавања, приликом обраћања лицима краљевске титуле и сл. Другом лицу множине у српском језику могућ је еквивалент неодређеноличне реченице у руском језику. Друго лице може бити изражено и безличном реченицом. А када се жели појачати категоричност, употребљава се облик једнине императива у функцији множине у стилски обојеним контекстима и својствен је руском језику, мада је присутан и у српском језику, напримјер у командама.

8. С обзиром на истражени материјал можемо рећи да су мишљења о статусу трећег лица различита. Постојање и статус трећег лица у оквиру категорије лица са теоријског становишта често је био предмет неслагања међу ауторима уџбеника и граматика. Непостојање трећег лица заговара се на основу тога да треће лице постоји само због одређених околности или услова комуникације. 
Ми прихватамо ставове према којима се треће лице сматра дијелом категорије персоналности јер је треће лице, када оно означава живо биће, у суштини ,ja" или „,ти” лице с тим што се у датом тренутку оно налази ван оквира директне комуникације, тј. и „он” је „,mu” само што „он” није присутно у датој говорној ситуацији. Оправданост укључивања трећег лица у круг лица и сферу категорије персоналности доказује се укључивањем у конкретну говорну ситуацију „он” које заузима позицију ,ja”, али и позицију „ти (ви)” када се првобитно говорно лице обраћа првобитном трећем лицу.

У трећем лицу најчешће је заступљен приповједачки стил, који се користи намјерно из више разлога. Неки истраживачи су сматрали да се облици трећег лица, због директног неучествовања у дијалогу, не могу замјењивати другим облицима. Међутим, треће лице може бити изражено и неким другим лицима. Застарјела форма у разговорном језику тиче се замјене трећег лица једнине са трећим лицем множине. Треће лице једнине у руском језику може бити изражено и трећим лицем множине са неодређеноличним значењем, а могуће је и обрнуто изражавање, тј. треће лице множине може бити изражено и другим лицем једнине. У српском језику значење трећег лица једнине може да има безлична конструкција са рјечцом се, посебно у приповједачком стилу, а такве конструкције у руском језику су ријетке. Чест начин изражавања радње трећег лица једнине у руском језику су облици са другим лицем једнине, а постоје примјери за уопштавање радње трећег лица. Треће лице једнине може бити изражено и првим лицем множине са социјално-инклузивним значењем и навијачком лексиком.

Као што се види, српском језику примјерима из руског језика одговарају личне и безличне реченице, са истом или другачијом структуром. За изражавање радње трећег лица једнине у руском језику употребљавају се и безличне реченице са инфинитивом као главним чланом. За разлику од српског језика, треће лице једнине у руском језику може да буде изражено обликом императива у неимперативном значењу када се изражавају различите модалне нијансе и значења радње. Уопште узев, у руском језику више су заступљене конструкције у којима у функцији субјекта фигурира неки члан у зависном падежу, него што је то случај са српским језиком за који су карактеристичне номинативне конструкције и реченице уопштеног карактера које у површинској структури не садрже члан који би означавао субјекат. Због тога је руски језик богатији са доста конструкција које су ријетко заступљене у српском језику, а с друге стране, у српском језику не постоје безличне реченице којих нема у руском језику.

На крају, сматрамо да је наше истраживање допринијело расвјетљавању неких питања на плану конфронтативног проучавања руског и српског језика из области категорије лица и глаголских једночланих реченица и дало повода за наставак неких других истраживања везаних за ову тематику. 


\section{ЛИТЕРАТУРА}

Бабайцева 2004: В.В. Бабайцева. Система односоставных предложений в современном русском языке. Москва, Дрофа.

Виноградов 2001: В.В. Виноградов. Русский язык (Грамматическое учение о слове) / Под ред. Г.А. Золотовой. 4-е изд. Москва: Русский язык.

Галкина-Федорук 1958: Е.М. Галкина-Федорук. Безличные предложения в современном русском языке. Москва: изд-во Московского ун-та.

Грамматика 1948: Грамматика русского языка. Ч. II. Синтаксис. / Под ред. Л.В. Щербы. Москва.

Грамматика 1954, 1960: Грамматика русского языка. Т. 2. Синтаксис, ч. I-II. Москва, изд-во АН СССР.

Грамматика 1970: Грамматика современного русского литературного языка. / Под ред. Н.Ю. Шведовой. Москва.

Грамматика 1979: Русская грамматика. T.II. Синтаксис. Academia, Praha.

Грамматика 1980: Русская грамматика. Т. 2. Синтаксис. Москва, Наука, изд-во АН СССР, Институт русского языка.

Золотова 1973: Г.А. Золотова. Очерк функиионального синтаксиса русского языка. Москва.

Ивић 1963: M. Ivić. Osnovne tipološke karakteristike srpskohrvatske impersonalne rečenice. - Књижевност и језик, X, 1, 18-24.

Кордић 2002: S. Kordić. Riječi na granici punoznačnosti. Zagreb: Hrvatska sveučilišna naklada.

Лалевић 1962: М. С. Лалевић. Синтакса српскохрватскога књижевног језика. Београд: Завод за издавање уџбеника.

Мароевич 1993: Р. Мароевич. Неопределенноличные предложения в русском языке и их сербские эквиваленты (О соотнотении сопоставительной лингвистики и теории перевода). - Вопросы языкознания, № 2, с. 96-106.

Маројевић 1977: Р. Маројевић. Реченице са уопштеноличним значењем у руском језику у поређењу са српскохрватским. Посебан отисак из Јужнословенског филолога, књ. XXXIII, Београд, 99-116.

Маројевић 2000: Р. Маројевић. О неодређеноличним реченицама у руском језику и проблемима њиховог превођења (поводом једне лингвистичке интерпретације). Српски језик данас, Београд: ЗИПС, Српска радикална странка, 227-233. 
Пешковский 1956, 2001: А.М. Пешковский. Русский синтаксис в научном освещении. Москва.

Пипер и др. 2005: П. Пипер, И. Антонић, В. Ружић, С. Танасић, Љ. Поповић, Б. Тошовић. Синтакса савременог српског језика. Проста реченица. У ред. Милке Ивић. Београд: Институт за српски језик САНУ, Београдска књига, Матица српска.

Синтаксис 1974: Синтаксис русского языка. Praha: Statní pedagogické nakladatelství.

Стевановић 1969, 1991: М. Стевановић. Савремени српскохрватски језик. Т. II. Синтакса. Београд: Научна књига.

Стевовић 1960: И. Стевовић. Функционална граматика српскохрватског језика. Београд: Завод за издавање уџбеника Народне републике Србије.

Шалютин 1980: Шалютин С.М. Язык и мышление. Москва.

Шахматов 1941: А.А. Шахматов. Очерк современного русского литературного языка. Москва, Учпедгиз.

Шахматов 2001: А.А. Шахматов. Синтаксис русского языка. Изд. 3. Москва, Эдиториал УРСС.

Якобсон 1972: Р.О. Якобсон. Шифтеры, глагольные категории и русский глагол. - Принципы типологического анализа языков различного строя, Москва, Наука, с. 95-113.

\section{Извори}

Андрић И. На Дрини ћуприја. Београд, Рад, 1990.

Андрич И. Мост на Дрине. Перевод Т. Вирты. Москва, изд-во Художественная литература, 1974.

Булгаков М. Мајстор и Маргарита. Превод Злата Коцић. Подгорица, Daily Press, 2003.

Булгаков М. Мастер и Маргарита. Санкт-Петербург, изд-во „Азбука-классика", 2005.

Достојевски Ф. Дечко, књига 1 и 2. Превод Милена и Радмило Маројевић. Горњи Милановац, Дечје новине; Београд, Српски фонд словенске писмености и словенских култура; Москва, Радуга, 1992.

Достоевский Ф. Подросток. Москва, изд-во Советская Россия, 1977.

Лалић М. Лелејска гора. Београд, Нолит, 1965. 
Лалич М. Лелейская гора. Перевод Т. Вирты. Москва, изд-во Художественная литература, 1989.

Толстој Л. Васкрсење. Просвета-Рад, Београд, 1975.

Толстой Л. Воскресение. Москва, изд-во Художественная литература, 1976.

Ћупић М. Окамењена нимфа. Ријека Црнојевића, Ободско слово, 1999.

Чупич М. Окаменевшая нимфа. Перевод Марианна Киршова. Москва, изд-во Гениус, 2007.

\section{КАТЕГОРИЯ ЛИЦА В ОДНОСОСТАВНЫХ ПРЕДЛОЖЕНИЯХ В РУССКОМ И СЕРБСКОМ ЯЗЫКАХ}

\section{Резюме}

Этот тип предложений для исследования категории лица выбран потому, что он лишь частично изучен и до сих пор нет единственного и окончательного мнения о нем, независимо от актуальности изучения его семантической структуры в последние десятилетия. Категория лица детально обсуждена и описана во всех славянских языках, но мы нашли немного работ, касающихся ее описания в нескольких славянских языках или во всех славянских языках. Поэтому мы считали, что результаты нашего сравнения сходства и особенно различия могут быть полезны следующим исследователям этой темы, а также и в учебных целях.

Основные задачи при выполнении этой работы сформулированы следующим образом: изучение и описание категории лица в односоставных предложениях на материале русского и сербского языков; анализ эволюции взглядов на глагольные односоставные предложения в русском и сербском языках; способы выражения определенноличности, неопределенноличности, обобщенноличности и безличности, а также способы выражения конкретного лица (первого, второго и третьего); взаимное сравнение и выделение их характеристик, особенно на основе различий во втором языке.

Ключевые слова: категория лица, односоставные предложения, определенноличные предложения, неопределенно-личные предложения, обобщенно-личные предложения, безличные предложения, выражение первого, второго и третьего лица. 